Revista do CESP, Belo Horizonte, v.34, n.52, p. 77-99, 2014

\title{
O escritor no espaço da obra: o rosto caligrafado - uma leitura de Apresentação do rosto, de Herberto Helder
}

\author{
The Writer in the Work Area: a Reading of \\ Apresentação do Rosto, of Herberto Helder
}

Ana Cristina Joaquim

Universidade de São Paulo (USP), São Paulo, São Paulo, Brasil

wiquen@gmail.com

Resumo: Trata-se de uma leitura de Apresentação do rosto, de Herberto Helder, em que as incursões pela escrita do "eu" são evidenciadas de modo a considerar a metalinguagem envolvida na elaboração subjetiva. Para tanto, traçamos um breve percurso, passando pelos teóricos que pensaram a autobiografia, o autorretrato e a escrita intimista, de modo geral, de forma que a problematização das categorizações genéricas se farão ver no desenvolvimento da análise textual. A seguir, levantamos questões acerca da constituição do sujeito da escrita mediante as relações estabelecidas entre o "eu" (Autor que se escreve, homem, filho) e os "outros" (leitor que se lê, mulher, mãe).

Palavras-chave: Escrita do eu; metalinguagem; subjetividade

Abstract: This is a reading of Apresentação do rosto, of Herbert Helder, in wicth incursions by selfwriting are highlighted in order to consider the metalanguage involved in the subjective writing approach. To do so, we draw a short route passing by theorists who thought the autobiography, the self-portrait, and the intimate writing, in general, so that the questioning of generic categorizations will be problematized during the textual analysis. After that, we raise questions about the constitution of the writing subject by the relations between the "self" (that in the text is the "Author" in the process of writing, a man, a son) and the "others" (the "readers" in the process of lecture, the woman, the mother).

Keywords:Self-writting; metalanguage; subjectivity 
Recebido em 30 de janeiro de 2014. Aprovado em 07 de junho de 2014.

\title{
Apresentação do rosto: a(s) polêmica(s) de que se faz
}

\begin{abstract}
Imagine-se agora que pretendo apresentarme o meu próprio rosto. Estou logo metido num caso policial. Colecciono pormenores e suspeitas, sigo uma pista que abandono, volto ao começo que já não é o mesmo começo mas o começo de outros começos. Uma confusão. Evidentemente não se chega a descobrir coisa alguma. Todos os crimes são crimes perfeitos.
\end{abstract}

Herberto Helder

$7 \mathrm{~m}$ estudo de Diana Pimentel, lemos que Apresentação $\checkmark$ do rosto, publicado em 1968, é retirado de circulação pela censura neste mesmo ano de sua publicação e, quase simultaneamente, vem a decisão de Herberto Helder de excluir o livro do conjunto total de sua obra. Eis o crime de olhar-se no espelho com a caneta na mão: a censura também o reconhece e certamente por motivos bastante diversos daqueles a que Herberto Helder nos deixa entrever mediante a citação inicial (o crime como metáfora do interdito? O autoconhecimento como interdito? A investigação, por meio da escrita, como fim em si mesmo? O fim como eterno recomeço?).

A posterior inclusão de algumas das partes de $A R$ em livros ulteriore ${ }^{1}$ confirma um fato recorrente ao longo de sua prática criativa: a constante revisão de seus escritos, aderência a um princípio de mobilidade que ecoa na temática da metamorfose. Como bem aponta Maurício Salles, em Helder há grande clareza a respeito do inacabamento da linguagem:

O elemento de autoposição do escrito como trabalho em continuidade, próprio de uma não obra [poderia pontuar Blanchot], sempre a ser reunido, ainda não encerrado, não fixado nas miragens da autoria e da cultura, uma vez que sua totalização está sendo revista e repensada em função do conjunto e de suas conjunções no tempo. ${ }^{2}$

\footnotetext{
${ }^{1}$ As informações acerca do destino das partes de Apresentação do rosto podem ser encontradas em: FREITAS, 2001, p. 21-22.

${ }^{2}$ VASCONCELOS, 2010, p. 199.
} 
Retomaremos essa prática metamórfica em momento adequado. Por agora, importa um desvio que nos encaminha para uma polêmica muito comum entre os críticos de Apresentação do rosto. Ainda no mesmo estudo de Diana Pimentel, nos deparamos com a seguinte afirmação:

Na medida em que Apresentação do Rosto se constitui, tal como é editorialmente classificada, como uma "autobiografia romanceada" - ou, na perspectiva de Américo Lindeza Diogo, um dos críticos (nem sempre claro e evidente) que mais se tem detido sobre os textos de Helder, uma "biografia problemática [...] que vem, na obra herbertiana, [...] situar a figura do autor" (Diogo, 1990: 9); na medida em que esta "autobiografia", reescrita, em fragmentos selecionados, em Photomaton \& Vox, inclui textos explicitamente autobiográficos, esses são os lugares privilegiados para se poder, por um lado, observar os mecanismos textuais e discursivos por que se dá forma ao retrato do autor e, por outro, averiguar da possibilidade de ser esse o modo de dar origem à experiência da escrita. ${ }^{3}$

Importa aqui, além da associação entre vida e obra, a noção de autobiografia difundida pela crítica: de acordo com Lejeune, para que se fale em relato autobiográfico, "é preciso que haja relação de identidade entre o autor, narrador e o personagem", ${ }^{4}$ sendo que essa identidade pode se manifestar de modo implícito - como no "uso de títulos que não deixem pairar nenhuma dúvida quanto ao fato de que a primeira pessoa remete ao nome do autor" ou na "seção inicial do texto onde o narrador assume compromissos junto ao leitor, comportando-se como se fosse o autor, de tal forma que o leitor não tenha nenhuma dúvida quanto ao fato de que o 'eu' remete ao nome escrito na capa do livro, embora o nome não seja repetido no texto" - ou de modo explícito, "no que se refere ao nome assumido pelo narrador-personagem na própria narrativa, coincidindo com o nome do autor impresso na capa". ${ }^{5}$

$\mathrm{O}$ caso de $A R$, segundo a proposta de classificação de Lejeune, situar-se-ia num dos modos implícitos de manifestação da relação de identidade acima descrita, uma vez que nele nos deparamos com a assunção

\footnotetext{
${ }^{3}$ PIMENTEL, s/d, p. 43.

${ }^{4}$ LEJEUNE, 2008, p. 15.

${ }^{5}$ LEJEUNE, 2008, p. 27.
} 
de um compromisso junto ao leitor (como veremos a seguir), embora no título não apareça a primeira pessoa (primeiro modo de manifestação implícita); tampouco seja possível afirmar absolutamente que o nome assumido pelo narrador-personagem coincida com o nome do autor - em Helder, o narrador-personagem é nomeado como "Autor". Lemos nas linhas introdutórias do livro: "Sou o Autor, diz o Autor [...]", ${ }_{6}^{6}$ vale frisar, grafado com inicial maiúscula, como se se tratasse de um nome próprio. Este fato gera uma ambiguidade de partida, já que não há garantia de que o "Autor" em questão corresponda estritamente à pessoa empírica Herberto Helder (modo de manifestação explícita). Considerando a variação do foco na dramatização do discurso: de primeira a terceira pessoa (em alguns momentos, a segunda pessoa também é evocada), lançamos a hipótese de que, no caso de Helder, uma investigação sobre si implicaria numa investigação sobre o humano, isto é, tratar-se-ia, levando a hipótese às últimas consequências, de uma investigação ontológica, em que, como aqui se apresenta, o indivíduo seria apenas uma parte do todo que se investiga. A ambiguidade, portanto, reside no fato de que a figura do Autor seria uma remissão, por um lado, a si próprio (Herberto Helder na condição de autor), bem como, por outro lado, uma investigação - mediante a escrita - sobre as paixões, as formas de conhecimento e os percalços de caráter amplamente humano, sempre em relação com uma perspectiva totalizante.

Nas páginas iniciais do livro estaria presente esta espécie de compromisso junto ao leitor (segundo modo de manifestação implícita), sobre o qual dissemos há pouco, já que, algumas páginas adiante, nos deparamos com os trechos a seguir: "Temos enfim o silêncio: é uma autobiografia. / É algo que se conquista à força de palavras", ${ }^{7}$ e pouco adiante: "E ele realizará uma autobiografia activa, uma sufocante acumulação de crime. [...] / Estou descontente. / Eis o inverno do meu descontentamento. Autobiografia. [...] / O autobiógrafo é a vítima do seu crime". ${ }^{8}$ Se partíssemos desta classificação, seria possível dizer que se trata de uma espécie de relato autobiográfico, ou, como no trecho supracitado de Diana Pimentel, na esteira editorial, de um romance autobiográfico.

Optamos, entretanto, por suspender essa possibilidade de leitura, uma vez que consideramos a definição de Lejeune um tanto

\footnotetext{
${ }^{6}$ HELDER, 1968, p. 13.

${ }^{7}$ HELDER, 1968, p. 16.

${ }^{8}$ HELDER, 1968, p. 17.
} 
insuficiente para o presente propósito. Essa insuficiência, a nosso ver, se deve, especialmente, a dois motivos: ele não trata, de maneira mais minuciosa, dos recursos estéticos/ficcionais que estariam em jogo - em certos momentos, nos parece que ele se ocupa da autobiografia mais no sentido de um relato histórico do que literário -, além disso, ele considera como critério de definição a impressão indubitável do leitor, tal como flagramos nos trechos citados: "uso de títulos que não deixem pairar nenhuma dúvida [...]" e "de tal forma que o leitor não tenha nenhuma dúvida [...]"; critério bastante polêmico, pois nem sempre a "certeza" acerca dos aspectos referidos será consensual. Ademais, ele atenta para o fato de que "o texto deve ser principalmente uma narrativa [...], a perspectiva principalmente retrospectiva [...], o assunto deve ser principalmente a vida individual [...]", ${ }^{9}$ características que não correspondem à estratégia de composição de $A R$, que é, a um só tempo, um texto poético, ensaístico, dramático e narrativo; a perspectiva, por outro lado, oscila entre a retrospecção e a atualidade totalizadora das impressões (há, vale frisar, uma perspectiva holística que perpassa toda a obra de Herberto Helder e, desse ponto de vista, o indivíduo é como que parte de uma lógica totalizadora de funcionamento do mundo, o que veremos mais detalhadamente. Por esse mesmo motivo é que atentamos, anteriormente, para a problemática quanto ao fato da figura do Autor se referir, unicamente, a Herberto Helder, e enfatizamos o caráter ontológico de seu retrato); e, por fim, o assunto é, de algum modo, a vida: não a vida do indivíduo particularizado, como geralmente ocorre nas autobiografias, mas a do escritor no seu exercício de decifração holística.

Embora hesitemos em considerar $A R$ um romance autobiográfico, pelos motivos que expusemos acima, acreditamos, porém, não haver dúvidas a respeito de sua inserção naquilo que tangenciaria o gênero e que, de modo bastante amplo, denominamos escrita de si. Mais precisamente, arriscaríamos sugerir que se trata de um autorretrato ou, como teria sugerido Michel Beaujour, "autoinscrição", ${ }^{10}$ já que há uma transposição do termo das artes plásticas para as artes da escrita.

Pensar em $A R$ como um autorretrato (e mantemos, aqui, esse termo em detrimento de "autoinscrição", apenas por ser mais recorrente), nos permite observar um recurso bastante presente no texto em questão:

${ }^{9}$ LEJEUNE, 2008, p. 15.

${ }^{10}$ BEAUJOUR apud PIMENTEL, s/d, p. 31-32. 
a metalinguagem. Para Michel Beaujour: "o autorretrato põe em cena e dialetiza a tensão entre eu penso e eu escrevo"11 (no caso da palavra como matéria-prima, uma vez que, como afirmamos anteriormente, o termo é oriundo das artes plásticas). Se continuarmos pensando com Beaujour, temos que, no autorretrato, "a máquina da escritura convoca um tipo de memória, a um só tempo, muito arcaica e muito moderna, pela qual os eventos de uma vida individual são eclipsados pela rememoração de toda uma cultura, promovendo, desse modo, um paradoxal esquecimento do eu", ${ }^{12}$ descrição que se adequa perfeitamente àquilo que chamamos, em Herberto Helder, de uma perspectiva holística, em que a investigação de si, que passa pela retomada do passado, não se restringe apenas à história pessoal, mas esta, como veremos, servirá de âncora para o alcance de um entendimento total.

Clara Rocha também irá retomar a reflexão de Beaujour para tratar de um procedimento do autorretrato que nos interessa de perto: "o traço distintivo mais marcante do autorretrato é o facto de a sua escrita se ordenar analógica ou tematicamente - e não cronologicamente, por não possuir o dinamismo da narrativa", ${ }^{13}$ ou ainda, nas palavras do próprio Beaujour: "o autorretrato se distingue da autobiografia pela ausência de uma narrativa sequencial". ${ }^{14}$ Outra característica que distingue o autorretrato da autobiografia é que o primeiro "não possui qualquer horizonte de expectativa, porque não obedece a nenhum modelo: cada autor de autorretrato (re)começa o trabalho de escrita como se este fosse único no seu gênero", ${ }^{15}$ o que nos permite afirmar a "transgenereidade" de $A R$, o que confere ao livro grande peculiaridade. Também Manuel de Freitas irá situar $A R$ neste escopo, ressaltando o aspecto confessional presente no texto em questão: "Apresentação do rosto remete-nos, inevitavelmente, para a iminência de um (auto) retrato [...] [já que]

${ }^{11}$ BEAUJOUR apud PIMENTEL, s/d, p. 35. No original: "l'autoportrait met en scène et dialectise la tension entre je pense et $j$ 'écris".

${ }^{12}$ BEAUJOUR apud PIMENTEL, s/d, p. 35. No original: "la machine d'ecriture [...] une type de mémoire à la fois très archaique et très moderne par quoi les evénements d'une vie individuelle sont eclipses par la remémoration de toute une culture, apportant ainsi un paradoxal oubli de soi".

${ }^{13}$ ROCHA, 1992, p. 41.

${ }^{14}$ BEAUJOUR apud PIMENTEL, s/d, p. 33. No original: "l'autoportrait se distingue de l'autobiographie par l'absense d'un récit suivi".

${ }^{15}$ ROCHA, 1992, p. 42. 
cria no leitor uma expectativa de confessionalidade que, pelo menos em parte, se verá confirmada."16 Essa confirmação apenas parcial das expectativas em relação a um relato confessional deve-se a essa espécie de fusão entre perspectiva individual e perspectiva holística conforme prevê a nossa leitura, sendo que a perspectiva holística acaba por diluir, em certa medida, o caráter particular do relato.

\section{A cena, o ato: a obra como via para o (auto)conhecimento}

Passemos, então, à leitura de Apresentação do rosto. Obedecendo à nossa proposta de olhar para o resultado do livro como um autorretrato, começaremos por uma aproximação entre o texto helderiano e a leitura de As meninas, de Velázquez, proposta por Foucault em As palavras e as coisas.

O livro de Helder é dividido em seis partes: "os prólogos", "os ritmos", "as imagens", "as metáforas", "as palavras" e "os epílogos". ${ }^{17}$ Em vista dessa estruturação, confirma-se a leitura metalinguística para a qual apontamos rapidamente, já que o rosto é apresentado mediante divisões, cujos títulos são todos vocábulos que participam de um mesmo campo semântico: o da elaboração literária. Nessa primeira aproximação, faremos uma reflexão sobre a metalinguagem, tendo em vista que o ato da criação é tematizado (mediante a metáfora da Gênesis, como veremos), conjuntamente a um percurso vital deste eu, Autor, cujo foco recai sobre duas ideias em especial: as metamorfoses do eu, e os questionamentos sobre a possibilidade de conhecimento/entendimento da existência.

Considerando-se o título da obra, trata-se de fazer ver um rosto, a princípio, um rosto impessoal, sem qualquer marca ou especificação de referente. Na primeira linha, em "os prólogos", porém, já somos notificados de que se trata do rosto de um Autor, ou melhor, do Autor (dada a definição do artigo presente já no título: Apresentação do rosto, e não apresentação de um rosto...). O Autor, portanto, no ato mesmo de sua criação, tal como ocorre em As meninas, em que o pintor se retrata no instante mesmo de estar a retratar. O Autor (assim como o pintor) se mostra ao leitor/espectador, aqui colocado na posição de plateia de

\footnotetext{
${ }^{16}$ FREITAS, 2001, p. 39.

${ }^{17}$ Optamos, entretanto, por uma análise que não obedeça à divisão das partes, mas a uma divisão temática, tendo em vista que os temas que elegemos se repetem ao longo do livro.
} 
um drama que será encenado: "E as pessoas que assistem são estátuas com cabelo, um sorriso talvez - com esse ar ambíguo das estátuas: branco, fatal, atônito", ${ }^{18}$ e continua: "As estátuas não têm amor nem adivinhação. / Estão cravadas nas poltronas e nada fazem por esse Autor repentinamente aparecido no meio de sombras e luzes." ${ }^{19}$ Lemos ainda: "[trata-se de] uma coisa poética, pela qual procurarei dar a impressão de que repito o acto iluminante do Génesis", fala este eu Autor, e, logo adiante, "Os poetas arrogam-se o direito de recomeçar o mundo". ${ }^{20}$ Notase, de imediato, a divisão dos papéis, em que a figura do Autor oscila entre a posição de primeira e de terceira pessoa, colaborando com uma dinâmica de aproximação e distanciamento ou, mais precisamente, com uma dinâmica que alterna entre ipseidade e alteridade (dinâmica que se dá na figura mesma do Autor, a um só tempo protagonista do drama e criador deste). Importa, ainda, a condição conferida ao Autor/poeta: solitário como o deus da criação, ele "aproxima-se das pessoas que estão simplesmente a assistir e lhe deixam, a ele, a solidão incólume." ${ }^{21}$ Num momento posterior, nos deparamos com a seguinte afirmação: "Estou só: escrevo". ${ }^{22}$ Temos, então, um dado bastante recorrente em algumas vertentes da escrita de si, como é o caso do diário e da escrita intimista: a reclusão do autor, o seu isolamento. Tal procedimento permitiria ao sujeito da busca voltar-se para si com o intuito de examinar sua subjetividade, fato que em $A R$ ocorre de maneira bastante peculiar, isto é, com uma variação determinante: este isolamento não é total. Se há, por um lado, a ênfase na solidão, há também uma aproximação em direção aos que assistem - ainda que essa aproximação não seja o bastante para romper com a solidão incólume do Autor.

Se pensarmos no caso de As meninas, nos deparamos com uma hipótese de leitura de Foucault que pode servir de mote para uma comparação:

O pintor olha [...] fixa um ponto invisível, mas que nós, espectadores, podemos facilmente determinar, pois que esse ponto somos nós mesmos: nosso corpo, nosso rosto, nossos olhos. O espetáculo que ele observa é, portanto, duas vezes

\footnotetext{
${ }^{18}$ HELDER, 1968, p. 13.

${ }^{19}$ HELDER, 1968, p. 13.

${ }^{20}$ HELDER, 1968, p. 14.

${ }^{21}$ HELDER, 1968, p. 13.

${ }^{22}$ HELDER, 1968, p. 17
} 
invisível: uma vez que não é representado no espaço do quadro e uma vez que se situa precisamente nesse ponto cego, nesse esconderijo essencial onde nosso olhar se furta a nós mesmos no momento em que olhamos [...] o olhar do pintor, dirigido para fora do quadro, ao vazio que lhe faz face, aceita tantos modelos quanto espectadores lhe apareçam. ${ }^{23}$

Essa ilusão do olhar criada por Velázquez, que faz com que o espectador seja, a um só tempo, observador e observado, se dá, embora em menor grau, também em $A R$, uma vez que é para o leitor que o Autor de $A R$ olha no momento inicial do seu ato de criação. Mediante um recurso dramático apropriado por Herberto Helder, a plateia de $A R$, por sua vez, reivindica do autor uma via de acesso à obra: "Onde estão as portas?", ${ }^{24}$ ao que o Autor responde de modo hesitante: "Com licença a todos, o Criador aqui sou eu. Se o Criador, dizia, lhes não desse uma porta." ${ }^{25}$ Este pequeno trecho é concluído, algumas linhas seguintes, com o seguinte temor da parte do Autor/Criador em relação a sua plateia: "[...] se calhar não chegam a compreender que é para elas [pessoas/plateia] tudo o que se faça." ${ }^{26}$ Ora, temos, então, um procedimento bastante complexo em $A R$ : nos deparamos, aqui, com um autor que se apresenta como um solitário (nos moldes, como já dissemos, do sujeito recluso da escrita intimista); sua solidão, entretanto, é colocada diante da/o plateia/leitor e a ela/ele oferecida como o ato de criação que imita, nas palavras do Autor, a Gênesis. Na sua solidão, é imprescindível a presença do outro/ leitor, uma vez que este é diversas vezes reivindicado, como atesta o longo trecho que aqui transcrevemos em parte (e a continuação seguirá logo adiante, obedecendo ao nosso percurso interpretativo):

Leia-se esta paisagem da direita para a esquerda e vice-versa, ou vice-versa e debaixo para cima, pode-se saltar as linhas que tremem debaixo dos olhos.

Pode-se ler a cavalo, de pé, ou sentado numa cadeira.

Pode-se sentar a paisagem numa cadeira e lê-la com extrema violência.

É uma paisagem de répteis, de ovos e de máquinas que não calculam.

Há no meio uma flor como a flor segregada pela boca das abóboras.

Quem leia, se ler, leve consigo a flor fria e amarela, crave o pedúnculo no

${ }^{23}$ FOUCAULT, 1987, p. 21.

${ }^{24}$ HELDER, 1968, p. 15.

${ }^{25}$ HELDER, 1968, p. 15.

${ }^{26}$ HELDER, 1968, p. 15. 
coração, e durma com o sangue e a sua dor de pessoa.

Quem aprender, que sonhe, que lhe cresça o cabelo tumultuosamente, que saiba, saiba até as portas da morte $[\ldots] .^{27}$

Nesse trecho, importa a forma pela qual se estabelece o elo Autor/leitor: as indicações colocadas pelo Autor como que desorganizam o percurso de leitura, uma vez que abarcam uma gama tão extensa de possibilidades (note-se o uso frequente dos conectivos "e" e "ou", bem como do verbo "poder") - marcadas pelas metáforas mais inusitadas que poderiam assumir as mais diversas referências (a depender do leitor... da força com que se deixa abarcar pela "violência") - que o elo, para que se cumpra, exige apenas essa espécie de disposição para o aprendizado do sonho, do tumulto, da "sua dor de pessoa", da morte. Trata-se, portanto, de um elo sem concessões, em que o leitor refaz à sua maneira o trajeto já previamente desorganizado pelo qual, simultaneamente, percorre o Autor. A leitura, no limite, exige plena cumplicidade diante do crime que se comete pela escrita, para retomar a metáfora com a qual iniciamos estas reflexões.

A relação Autor/leitor se complexifica ainda mais se atentarmos para o fato de que, em Helder, a criação ou o ato da escrita confunde-se com um processo de busca pelo conhecimento. Essa busca, como veremos no tópico subsequente, implica uma relação com a memória individual que, entretanto, extrapola o domínio particular para abarcar uma ideia de existência total, na qual estaria em destaque uma investigação ontológica e, portanto, não restrita a um único indivíduo (no caso, o Autor, protagonista da busca), mas de pertinência para todos os envolvidos, isto é, os leitores são necessariamente incluídos nesta jornada.

Mais uma vez, lançamos mão de Foucault, na sua interpretação do quadro de Velázquez:

Olhamo-nos olhados pelo pintor e tornados visíveis aos seus olhos pela mesma luz que no-lo faz ver. E, no momento em que vamos nos apreender transcritos por sua mão como num espelho, deste não podemos surpreender mais que o insípido reverso. O outro lado de um reflexo. ${ }^{28}$

Ora, o espelho de que só vemos o reverso em Velázquez, mantendo enigmática a nossa imagem, aparece em Helder para se referir ao leitor, bem como ao Autor. No caso do leitor, vale reproduzir o seguinte

\footnotetext{
${ }^{27}$ HELDER, 1968, p. 183.

${ }^{28}$ FOUCAULT, 1987, p. 22.
} 
trecho, que abre o capítulo "as palavras": "Leia-se conforme for com acordar de noite tremendo de espanto. / Leia-se como um milagre cheio do milagre dos erros. / Leve-se para a vigília essa visão como um espelho. / Espelho, procedimento de expansão ardente." ${ }^{29}$ (nota-se a ambiguidade na partícula se, que pode ser lida tanto como índice de indeterminação do sujeito, tal como ocorre em "leve-se para a vigília essa [...]" ou como pronome reflexivo, em que o leitor seria conduzido por esta espécie de didascália do Autor, a ler-se a si mesmo, já que a imagem do espelho se faz presente). No caso do espelho diante do Autor, selecionamos trechos em que a primeira pessoa é evocada: "inclino para o guarda-fatos minha cara, o espelho põe-me diante de um novo objecto de ciência". ${ }^{30}$ Essa confissão por parte do Autor ocorre após uma série de relatos que perpassam anos de vivência na busca pelo conhecimento (voltaremos a isso mais detalhadamente), além de suceder à seguinte afirmação: "eu sou um movimento". ${ }^{31} \mathrm{O}$ espelho (metáfora para o autoconhecimento) tornase instrumento insuficiente para o sujeito da busca, pois, se, em Velázquez, o espectador não tem acesso ao seu retrato; em Helder, o sujeito está em constante transformação (o sujeito, inclusive, é "objetualizado", tornado outro, "novo") o que torna impossível a apreensão plena de si. A transformação aparece em outros escritos de Herberto Helder e, como podemos atestar na seguinte passagem do conto "Teoria das cores", seria uma espécie de lei universal:

Era uma vez um pintor que tinha um aquário com um peixe vermelho. Vivia tranquilamente o peixe acompanhado pela sua cor vermelha até que principiou a tornar-se negro a partir de dentro, um nó preto atrás da cor encarnada. $\mathrm{O}$ nó desenvolvia-se alastrando e tomando conta de todo o peixe. Por fora do aquário o pintor assistia surpreendido ao aparecimento do novo peixe [...]. Ao meditar sobre as razões da mudança exatamente quando assentava na sua fidelidade, o pintor supôs que o peixe, efetuando um número de mágica, mostrava que existia apenas uma lei abrangendo tanto o mundo das coisas como o da imaginação. Era a lei da metamorfose. ${ }^{32}$

\footnotetext{
${ }^{29}$ HELDER, 1968, p. 183.

${ }^{30}$ HELDER, 1968, p. 89.

${ }^{31}$ HELDER, 1968, p. 89.

${ }^{32}$ HELDER, 2005, p. 21-22.
} 
Há trânsito de cores, de formas, há trânsito de sentido, portanto. Tudo sofre de perpétua movimentação, o que impossibilita que qualquer conceito ou lei seja derivada mediante os padrões da verdade científica: não há permanência.

A imagem do espelho aparece, ainda, e diversas vezes associada à ideia de obscuridade: "Espelho negro. Vê-se que sabes tudo, que esgotaste a tua difícil ciência". ${ }^{33}$ Nesse caso, parece coerente pensar que o esgotamento da difícil ciência de si é devido, não ao seu alcance, mas à sua impossibilidade, dada a qualificação do espelho em oposição à luz, e, consequentemente, em oposição ao iluminismo racional que a ciência, mediante a clara exatidão, poderia comportar. Saber tudo significaria, então, saber a impossibilidade de se saber, isto é, saber que existe o enigma. Em outro momento, retomando a citação: "Leia-se como um milagre cheio do milagre dos erros. Leve-se para a vigília essa visão como um espelho". ${ }^{34} \mathrm{O}$ erro como uma visão associada ao espelho, ou, o espelho que reflete a desaparição: "Tenho medo do teu rosto que desaparece um pouco loucamente, como se parasses para ver o outro lado do espelho." ${ }^{35}$ Novamente, a menção à loucura: "Os espelhos são negros como os jacintos da loucura", ${ }^{36}$ e uma variante da loucura - a embriaguez - desta vez qualificando os espelhos que seriam, entretanto, uma parcela do ofício de ver, em remissão ao sujeito: "É possível ainda cortar ao meio o ofício de ver - e num lado há espelhos bêbedos, no outro, um cardume ilegível de sons obscuros" ${ }^{37}$ Há ainda que se ater a essa imagem sinestésica que aqui se manifesta às avessas: um cardume ilegivel de sons obscuros só redundaria uma multiplicidade de sensações, como prevê a sinestesia, se os aspectos em relação fossem passíveis de decodificação pelos sentidos, o que não ocorre em absoluto, e por isso dissemos dessa sinestesia às avessas, esta espécie de percepção fugidia que se confunde na imagem dos peixes (diversas vezes usados como metáfora do inconsciente e, portanto, daquilo que permanece velado), que são tanto impossíveis de ler, quanto de ouvir: não se fixa pela percepção.

No limite da metáfora especular, até então associada à noção de autoconhecimento, surge a noção do heteroconhecimento, ou, para

\footnotetext{
${ }^{33}$ HELDER, 1968, p. 171.

${ }^{34}$ HELDER, 1968, p. 183.

${ }^{35}$ HELDER, 1968, p. 190.

${ }^{36}$ HELDER, 1968, p. 191.

${ }^{37}$ HELDER, 1968, p. 193
} 
manter coerente a nossa linha interpretativa, a impossibilidade do heteroconhecimento, ou, do conhecimento total:

Bem: pode tomar-se um espelho e colocá-lo em frente das coisas.

Na melhor das hipóteses, onde era esquerdo fica direito e vice-versa.

Pode aparecer tudo negro noutros casos.

É porque as coisas são negras. ${ }^{38}$

Nesse caso, temos um espelho diante de "coisas" diversas, poderíamos dizer, diante do mundo, e ocorre também aqui a menção à impossibilidade: a remissão ao erro (mediante a inversão promovida pelo espelho) e ao obscuro, ao qual estariam condenadas as próprias "coisas". Importa o fato de que o espelho, objeto usado para a autoapreciação, é também requisitado no ato de olhar para o outro ou para o mundo (coisas), e daí poderíamos derivar o autoconhecimento intrinsecamente associado a qualquer outra espécie de conhecimento, de modo que aquela ponte traçada inicialmente entre eu e outro, entre Autor e leitor, adquire bases mais sólidas.

Uma vez que, tanto no caso do conhecimento de si, como no caso do conhecimento do mundo, o espelho é conotado com valores de insuficiência, podemos dizer que a busca empreendida pelo sujeito do conhecimento seria uma busca vã, dada a impossibilidade de captura. De certa forma, isto é, se tivermos como parâmetro a noção tradicional de conhecimento atrelado à racionalidade, não seria impertinente afirmálo, já que as questões que norteiam essa busca são as grandes questões presentes entre filósofos, literatos e, sem dúvida, entre os cientistas, tais como, a passagem do tempo: "Não se conte isso em tempo: foi muito tempo, ou foi muito pouco. / Não há tempo. Porque esta alegria, este amor, este medo que anda, esta violação servida por minúcias mesquinhas, estão prontos para o muito ou pouco tempo";39 as relações interpessoais - especialmente as familiares, que ocupam grande parte de $A R$ : "Mãe dizemos nós. / Mas a mãe foi tomada por aquela grande desatenção. / E chamamos pela jovem tremendamente irradiante e íntima. / Mas nada há, além de um nome inventado pelo nosso tempo e colocação, o nosso próprio mistério"; 40 a morte: "Todos os dias os mortos ressuscitam e

\footnotetext{
${ }^{38}$ HELDER, 1968, p. 199-200.

${ }^{39}$ HELDER, 1968, p. 65.

${ }^{40}$ HELDER, 1968, p. 32.
} 
bebem o meu sangue de homem, e eu sorrio-lhes, cheio de gratidão e amor." ${ }^{41}$ Questões essas sobre as quais é bastante difícil se pronunciar de modo racional ou ter alguma "clareza e distinção" (binômio que qualifica o conhecimento absoluto, de acordo com o racionalismo cartesiano).

Acontece que em Herberto Helder todas essas questões são expostas em consonância com um percurso de criação - e, sendo assim, a busca pelo conhecimento é simultânea à sua elaboração escrita - de modo que o conhecimento está atrelado à criação de um saber, neste caso, possível de ser reelaborado conforme as relações promovidas entre as partes de que se compõe o todo (o que ocorre incessantemente em $A R$, em que não há a preocupação em obedecer a uma lógica de composição causal, nem a uma sucessão temporal, tampouco ao princípio da não contradição), fato que confirma a sua adesão àquilo a que ele chamou lei da metamorfose, além de apontar para um conhecimento na e da obscuridade, difuso, que não depende da via racional, como é possível atestar mediante o uso dos vocábulos: erro, vigília, loucura, ilegível, obscuro -escolha lexical que confirma essa noção de conhecimento que subverte a lógica racionalista e se define no ato mesmo da criação artística. Sobre a sabedoria associada ao processo criativo da escrita e a sua metáfora inicial da Gênesis, vale citar o seguinte trecho, que encerra a segunda parte do livro, intitulada "os ritmos":

Tenho uma pequena ciência

Fiz como nos livros.

Dividi-me em sete dias.

Com os meus dez dedos enchi os dias, e depois com os meus ouvidos e o meu coração sôfrego.

$[\ldots]$

Depois pensei, como pode pensar um animal criador extenuado, porque eu tinha-me criado a mim mesmo, e era uma criatura quente e exausta, e estava cheio da dor e da alegria da minha obra - era então o sexto dia.

$[\ldots]$

Pela escrita tinha eu chegado ao sétimo dia, ligado tudo, ligando o que não é como que visível, mas é como que audível $[\ldots]^{42}$

${ }^{41}$ HELDER, 1968, p. 37.

${ }^{42}$ HELDER, 1968, p. 106-107. 
Importa ressaltar dois aspectos: a ciência/sabedoria enquanto resultado da criação; e a criação enquanto ato reflexivo (no sentido de criarse a si mesmo). Os dois aspectos dependem, como indicado, da atuação escrita (Fiz como nos livros e Pela escrita tinha eu chegado ao sétimo dia). O sujeito se constitui pela escrita de tal modo que, quando a mão direita vale ressaltar, a mão da escrita ${ }^{43}$ - começa por se transformar, todo o sujeito também passa por uma transformação: "Claro, não amava ninguém, mas a minha vida era como que atravessada diariamente por um calor tranquilo e ligeiro. E então vi de repente que tinha uma nódoa branca na mão direita"; 44 a nódoa branca começa, então, a se alastrar pelo corpo até que opera uma transformação determinante no sujeito: "O meu amor pelas pessoas também crescia, varado por singular violência e fraqueza, um pânico, uma melancolia enormes", ${ }^{45}$ e sobre essa transformação, ele se pronuncia:

Contudo, penso às vezes que não era, nem é, uma doença física, algo como lepra ou coisa assim. [...] Talvez a lepra tenha me atacado noutro sítio, numa zona terrivelmente mais importante. Talvez entre o amor e o mundo haja uma chaga pior, onde nem mesmo se espere esquecer ou fugir. ${ }^{46}$

Importa notar novamente o apelo metalinguístico do trecho: a repercussão que uma mancha principiada da mão da escrita pode causar no sujeito, passando a determinar, inclusive, a força do amor e levando a um questionamento de ordem maior: seria mesmo possível pensar na escrita como propulsora dos caminhos e descaminhos, da saúde e da doença, a escrita como aparato totalizador, já que ela comporta, em Herberto Helder, as constantes modificações, e estas são, ao que parece, o único princípio imutável.

\section{A memória do indivíduo para além do indivíduo}

Cabe, neste momento, dar um salto para tratar mais detalhadamente daquilo que dissemos ser uma visão holística de mundo.

43 “Gosto da mão direita um pouco mais do que da outra, pois tenho aquela ideia tradicional de que ela é um nobre instrumento da obra e está ligada superiormente ao espírito.” (HELDER, 1968, p. 158).

${ }^{44}$ HELDER, 1968, p. 158.

${ }^{45}$ HELDER, 1968, p. 162.

${ }^{46}$ HELDER, 1968, p. 163. 
Há, na segunda parte de $A R$ ("os ritmos"), um longo trecho dedicado à memória, especialmente à memória da infância, na qual a presença familiar é marcante. Não se trata, porém, de um relato de cunho unicamente pessoal: embora algumas referências e escolhas pareçam incidir sobre eventos particulares, podemos dizer de um procedimento de universalização.

Há que se notar, entretanto, que o sujeito que fala é um homem e, mediante sua hombridade é que ele se situa no mundo: "Estarei reduzido à completa masculinidade", ${ }^{47}$ reflete o sujeito da enunciação aos oito anos de idade, num procedimento de atualização do passado, em que o sujeito, embora se apresente na idade de oito anos, possui o conhecimento e a perspectiva da idade futura (já que consegue prever o seu destino em direção à masculinidade), promovendo, assim, uma espécie de fusão intertempos. Nota-se ainda o caráter pejorativo da masculinidade que operaria com uma redução do sujeito. ${ }^{48} \mathrm{O}$ capítulo "as imagens" inicia-se com um diálogo entre um Homem e uma Mulher (grafamos em maiúscula, já que seriam personagens, em alguma medida, semelhantes à personagem Autor), numa situação amorosa, em que o Homem é vítima de uma invasão de esperma:

Já não sabia o que fazer, pois encontrava esperma entre as páginas dos livros, nos bolsos, nos cigarros. / Uma vez atirou fora os cigarros e gritou: porque está aqui esperma, nos cigarros? / Nem se pode fumar. / E depois como foi? [pergunta a Mulher] / Parece que o esperma invadia tudo. ${ }^{49}$

Ora, ser homem, por um lado, individualiza esse sujeito - e, por isso, poderíamos arriscar uma associação entre o sujeito da enunciação e o próprio Herberto Helder - mas, por outro lado, transgride os limites do particular: nessa forma de abordagem, não se trata de um homem, em particular, mas da condição masculina, aqui, mediada pela figura do Autor, protagonista textual que promove, por meio da escrita, essa via de acesso entre o eu e os outros, entre o sujeito particularizado e o todo receptivo, entre Autor e leitores.

\footnotetext{
${ }^{47}$ HELDER, 1968, p. 54.

${ }^{48}$ Em oposição à caracterização do feminino em sua obra, em que, vale dizer, a mulher é elevada ao potencial criador, como podemos notar em um dos inúmeros momentos em que essa tópica aparece: "O papel monumental pertence à mulher - é sempre assim, sempre. Possui a grandeza do destino, ela - é a terra a sua cegueira superior, a clarividência.” (HELDER, 1968, p. 99).

${ }^{49}$ HELDER, 1968, p. 111
} 
Veremos que todas as remissões ao passado passam por uma tentativa de entendimento que toma proporções totais, por assim dizer. Sobre essa amplitude que oscila entre o eu e o todo, vale citar as seguintes passagens: "É certo que falo das plantas, dos animais, do homem e da mulher - disso que se conseguiu: a idade." ${ }^{50}$ e, ainda: "Escrevo um livro, estou a falar de nós - nós que nos esperamos, homens por dilatar, com os poderes da emissão e da receptividade, os pontos imóveis onde apenas estávamos a ter atenção e expectativa." "51. Há, desse modo, essa espécie de compaixão: uma paixão compartilhada entre os homens, pois que falar sobre temas quaisquer significa possibilitar as vias da comunicação ("poderes da emissão e da receptividade"), de modo que falar sobre si é, em alguma medida, falar sobre todos, por isso o uso da primeira pessoa do plural. Em outras palavras, trata-se de debruçar-se sobre si, na medida em que se debruça sobre qualquer assunto possivelmente humano, como o são as plantas, os animais, o masculino, o feminino e as acepções culturais que significaram a oposição dos sexos através das gerações: referimo-nos aqui ao aspecto familiar, tal como foi interpretado pela psicanálise, em especial, uma vez que esta é reivindicada em diversas passagens.

Em remissão a Édipo ou, mais especificamente, à leitura freudiana que derivou no Complexo de Édipo, numa sugestão ao incesto, lemos: "Quando voltar a ver as antigas memórias, terei os pés cobertos de cicatrizes. Que pensarão de mim? Que sou um mártir? Um vagabundo a quem faltaram os sapatos? Um homem a quem faltou a prudência?"52 e, logo a seguir: "Porque, evidentemente, quem possui os pés marcados, não pode deixar de ser suspeito." 53 e, de forma mais explícita: "[...] é provável o aparecimento de Édipo-o-Jovem à entrada de Tebas." 54 De forma também abrangente, isto é, não particularizada, ele fala sobre a figura da mãe (não se trata de "minha mãe", mas de uma ideia psicanalítica de mãe):

A mãe é aquela face do enigma, no centro do labirinto, face da catástrofe, luz horrível que se recolhe como um ramo de flores venenosas. Resta ao filho, caminhar lentamente

\footnotetext{
${ }^{50}$ HELDER, 1968, p. 144.

${ }^{51}$ HELDER, 1968, p. 145.

${ }^{52}$ HELDER, 1968, p. 32.

${ }^{53}$ HELDER, 1968, p. 33.

${ }^{54}$ HELDER, 1968, p. 203.
} 
com a sua festa negra: o segredo que não se revela, o amor maldito, incesto, canto da sua glória tenebrosa. ${ }^{55}$

Vale atentar ainda, para uma última citação, em que o incesto, até então, expresso mediante a leitura psicanalítica, se transfigura numa espécie de decifração do ciclo vital, assumindo traços místicos e resultando em uma visão total/holística: "É a nova tentação do espírito: a união com a terra, a mãe." ${ }^{56}$ Importa notar, em contraposição, os raros momentos em que a figura do pai é evocada: ora, tratando-se de um sujeito masculino e, obedecendo à perspectiva psicanalítica, essa ausência se torna bastante compreensível item, e poderíamos pensar, inclusive, num assassinato metafórico do pai que, como se estivesse morto, é ausentado das memórias do sujeito.

Retomando, rapidamente, a discussão anterior, cujo foco recaiu sobre a ideia da obscuridade do conhecimento, nota-se a incidência dessa temática também associada ao mito de Édipo e ao mito bíblico: “Talvez espere um dia caminhar sobre as águas, recuperar tudo, chegar junto à esfinge que existe à entrada de todos os lugares e destituí-la de poderes, pela decifração dos enigmas." 57

A psicanálise aparece também como prática terapêutica, em consonância, arriscaríamos dizer, com a busca de si empreendida pelo sujeito da escrita: "Fui aos psicanalistas e mandaram-me deitar num divã. Tenho a alegria ou o terror - por onde devo começar? Fale do que quiser, diziam. Eu estava de olhos abertos, deitado na obscuridade do gabinete." 58 Nota-se, novamente, a busca - inalcançável - em direção ao autoconhecimento, uma vez que, embora de olhos abertos, como que dispostos à investigação de si, o gabinete é obscuro.

"Trata-se de uma metáfora", ${ }^{59}$ lemos no início do capítulo intitulado "as metáforas" e, algumas páginas adiante, "Não creiam que alguém possa se salvar. Não há uma verdadeira metáfora humana, um estilo": ${ }^{60}$ importa perceber a forma pela qual, mais uma vez, a transfiguração da vida em obra (metáfora) redunda numa impossibilidade, uma vez que não há a

\footnotetext{
${ }^{55}$ HELDER, 1968, p. 100.

${ }^{56}$ HELDER, 1968, p. 203.

${ }^{57}$ HELDER, 1968, p. 172.

${ }^{58}$ HELDER, 1968, p. 95.

${ }^{59}$ HELDER, 1968, p. 143.

${ }^{60}$ HELDER, 1968, p. 146
} 
metáfora da salvação. Ora, para além da ênfase no inacessível, vale fazer algumas considerações quanto ao aspecto fantasioso em que se inserem estas memórias. Para tanto, reproduzimos a seguinte passagem de Paul Ricoeur: "[...] a lembrança pertence ao 'mundo da experiência' frente aos 'mundos da fantasia', da irrealidade. O primeiro é um mundo comum [...], os segundos são totalmente 'livres', seu horizonte é perfeitamente "indeterminado." ${ }^{61}$ A despeito do fato de que estas linhas foram escritas por Ricoeur num contexto em que lhe interessava distinguir lembrança e irrealidade, acreditamos que, no presente caso, seja produtivo pensar de que maneira a atualização da fusão entre uma e outra, operada em $A R$, revela a ultrapassagem do individual ao coletivo, mediante os recursos literários. Essa indeterminação e liberdade de que são dotados os mundos da fantasia é que conferem grande autenticidade à formalização textual de $A R$, bem como seriam elas as responsáveis por "individualizar" esse texto e este sujeito autoral, por assim dizer; já que, em alguma medida, esse texto é também o resultado de experiências de uma vida. Entretanto, as experiências por si só, se abstraídas num grau quase científico (a descoberta da masculinidade em oposição à incompreensível feminilidade, as primeiras aventuras amorosas, a morte de entes próximos, a consciência dos diferentes espaços e culturas), ${ }^{62}$ apenas permitem filiar o sujeito/Autor, a uma cultura ocidental e fortemente influenciada pelo catolicismo e pela psicanálise freudiana, em que o sexo masculino é diferentemente conotado em relação ao sexo feminino. Em linhas gerais, o texto, assim abstraído de seu caráter fantasioso, poderia ser escrito por um sem número de autores, dada a correspondência axiológica entre os indivíduos circunscritos à comunidade cultural supramencionada. Neste caso, importa, portanto, aquilo que de fantasioso se mistura ou (re)compõe o mundo da experiência. É, então, de responsabilidade da fantasia o caráter identitário do texto/sujeito o que se deve, em última instância, à formalização textual, isto é, àquilo que Ricoeur confere à função narrativa: "[...] ninguém se dedica a explicar uma sequência de acontecimentos sem recorrer a uma colocação em forma literária expressa de caráter narrativo, retórico ou imaginativo", ${ }^{63} \mathrm{e}$, de forma mais abrangente, Mark Freeman confere à nossa condição, enquanto seres aptos

\footnotetext{
${ }^{61}$ RICOEUR, 2007, p. 66.

${ }^{62}$ Embora cada um desses aspectos merecesse uma análise pormenorizada, não será possível realizar aqui esta proposta dada a sua extensão.

${ }^{63}$ RICOEUR, 2007, p. 147.
} 
à linguagem: “[ ...] there may really be no 'lives' apart from this infinite play of language itself." ${ }^{64} \mathrm{O}$ próprio Herberto Helder está atento a esse fato: "Fazem uma vida com boa caligrafia, eles [os poetas] - e acabouse", ${ }^{65}$ associando, de maneira radical, vida e linguagem/ofício poético.

Vale retomar a temática "homem versus mulher" inscrita através da memória. Aqui, as figuras da mãe, das irmãs, da avó, e das amantes aparecem como "o outro" (melhor seria dizer "a outra") em função do qual esse sujeito se define. Os oito anos, idade constantemente evocada ao longo do livro, aparecem aqui, tal como disse Manuel de Freitas, como a "idade do sangue ou, se preferirmos, da descoberta do sangue enquanto ritual e certeza de morte", ${ }^{66}$ já que é então que "Em mim, uma alegria tão forte que se torna necessário fazer qualquer coisa. Tiro do bolso o meu pequeno canivete e, no braço nu, traço um golpe fundo. Vejo o sangue correr, o meu sangue." ${ }^{\circ 7}$ A partir desse momento é que parece ter início a sua jornada no universo masculino, como num ritual iniciático: "Estou ali, diante de todas as mulheres que me amam, e sangro por mim e por elas, e para elas." ${ }^{18}$ Subsequente a este evento, outro evento sangrento: os doze anos da irmã e a sua menstruação: "A irmã levantou os olhos da mesa, deixou cair a ameixa e ficou a olhar com espanto a parede em frente [...]. Tinha chegado o tempo do conhecimento." ${ }^{\circ 9}$ A seguir, lemos:

Comigo foi assim, pensa ele: golpeei o braço, expus-me, criança doce e dramática em frente do espanto e da comoção das mulheres, caí no abismo, ressuscitei sob a delicadíssima atenção feminina, cresceram-me os braços e as pernas, insinuou-se em mim um novo ritmo, soube que ultrapassei um perigo e fiquei de uma outra maneira diante de tudo [...]. Depois diz: aconteceu-lhe o mesmo a ela, mas de um modo particular [...]. Quanto ao sangue de uma irmã de doze anos que de repente pára de comer ameixas e olha a parede e fica em pânico e grita e atrai as mulheres e é arrastada para o fundo da casa - começo a saber uma pequena coisa. Tenho medo. ${ }^{70}$

\footnotetext{
${ }^{64}$ FREEMAN, 1993, p. 8.

${ }^{65}$ HELDER, 1968, p. 164.

${ }^{66}$ FREITAS, 2001, p. 41.

${ }^{67}$ HELDER, 1968, p. 46.

${ }^{68}$ HELDER, 1968, p. 48.

${ }^{69}$ HELDER, 1968, p. 59.

${ }^{70}$ HELDER, 1968, p. 60.
} 
Esse trecho não é apenas uma mostra da recorrência com que a diferença entre os sexos irá aparecer em $A R$. Mais do que isso, nele evidencia-se o primeiro aprendizado de si: a hombridade. Importa ressaltar a oscilação entre a primeira e a terceira pessoa do discurso que, neste caso, parece compor uma duplicidade temporal: a primeira pessoa marca o sujeito no passado, a idade dos oito anos, e a terceira pessoa, marca o sujeito no tempo presente que narra o fato de forma imparcial, ocupando-se apenas de inserir as marcas da enunciação ("pensa ele", "depois diz"). A análise se complexifica se atentarmos para os tempos verbais: a primeira pessoa, representando os oito anos, é conjugada no passado (como se a experiência fosse narrada pelo menino de oito anos como tendo já acontecido, o que sugere uma anterioridade imensurável e nos leva à hipótese de que se trataria de um evento ou conhecimento ancestral, perdido na História), enquanto a terceira pessoa conjugada no presente atualiza o evento que veio a dar neste conhecimento primordial. A última linha da citação, "começo a saber uma pequena coisa. Tenho medo.", se ocuparia em fazer a ligação entre os tempos passado e presente, já que subverte o padrão que detectamos, pois aparece em primeira pessoa e, rompendo com as nossas expectativas, é conjugada no tempo presente. Toda essa complexificação temporal nos permite afirmar, na linha interpretativa que viemos seguindo, uma noção de atemporalidade, ou seja, a tomada de consciência da masculinidade e da feminilidade como algo que é constantemente atualizado e, portanto, não pode ser considerado um conhecimento pleno, adquirido, já que depende sempre do momento presente. Desse ponto de vista, o indivíduo é, novamente, absorvido pelo todo: cultural, religioso ou científico do qual é parte (isso implica numa adequação ao seu tempo), e absorvido também pela presença da tradição cultural milenar da qual é herdeiro, o que enfatiza a perspectiva holística que acreditamos prevalecer em $A R$.

\section{Considerações finais}

Tendo em vista um texto bastante extenso e complexo, como é o caso de Apresentação do rosto, nos ocupamos, aqui, em elencar uma diversidade de aspectos que se relacionam com a escrita de si, tais como: a relação com o outro (Autor/leitor, filho/mãe, homem/mulher, sujeito/ mundo), a busca pelo conhecimento de si e pelo entendimento do outro e do mundo, a memória; além de considerar a dificuldade de classificação 
que, como tentamos mostrar, encontra na noção de autorretrato maior flexibilidade de abordagem do que na noção de autobiografia.

Cabe dizer, por fim, que, embora tenhamos insistido na perspectiva holística mediante a qual $A R$ se constitui formal e tematicamente, o caráter individual e subjetivo presente no livro não pode ser considerado de menor importância, já que a identidade do indivíduo aparece no texto por meio da recorrência à memória, por meio da condição decorrente da masculinidade e, mais importante, por meio do ofício da escrita que se confunde com a própria vida e com a constituição desse sujeito. Arriscaríamos dizer, que também a perspectiva holística contribui, de alguma maneira, para a visada subjetiva, posto que, se há um todo, ele é composto de partes, e o rosto que aqui se apresenta é, portanto, a parte mediante a qual o leitor - mas também o sujeito-Autor, que é, a um só tempo, criador e criatura do texto (de) que se faz - poderá vislumbrar esse todo logicamente incompreensível (em remissão à ideia de uma impossibilidade racional de conhecimento absoluto...), e, mediante a metáfora especular, reconhecerse, elaborar-se, desvencilhar-se, desta parte, e retornar a ela para a seguir recusá-la, numa suposição de que as metamorfoses são a única coisa que podem ser percebidas diante do espelho.

\section{Referências}

FOUCAULT, Michel. As meninas. In: . As palavras e as coisas.

São Paulo: Martins Fontes, 1987.

FREEMAN, Mark. Rewriting the self. London and New York: Routledge, 1993.

FREITAS, Manuel de. Uma espécie de crime: Apresentação do rosto de Herberto Helder. Lisboa: \&etc, 2001.

HELDER, Herberto. Apresentação do rosto. Lisboa: Ulisseia, 1968.

HELDER, Herberto. Os passos em volta. São Paulo: Azougue Editorial, 2005.

HELDER, Herberto. Photomaton \& Vox. Lisboa: Assírio \& Alvim, 2006.

LEJEUNE, Philippe. O pacto autobiográfico: de Rousseau à internet. Belo Horizonte: Editora UFMG, 2008. 
PIMENTEL, Diana. Ler a voz, ver o rosto: uma polaroide de Herberto Helder. Porto: Campo das Letras, s/d.

RICOEUR, Paul. A Memória, a História, o Esquecimento. Campinas: Editora da Unicamp: 2007.

ROCHA, Clara. A poética dos géneros autobiográficos. In: Máscaras de Narciso: estudos sobre a literatura autobiográfica em Portugal. Coimbra, 1992.

VASCONCELOS, Maurício Salles de. Espiral terra - poéticas contemporâneas de língua portuguesa. Tese de livre-docência. São Paulo: FFLCH-USP, 2010.

VELÁZQUEZ, Diego. As meninas. 1656. Óleo sobre tela. $320 \mathrm{~cm}$ x 276 cm. Madrid, Museo Nacional del Prado. 
